\title{
Analytical techniques and herbal Medicinal Plants: A Review of past and present techniques
}

\author{
Summyia Masood ${ }^{1 *}$, Nighat Shafi ${ }^{1}$, Saifa Amin $^{2}$, Hira Arshad ${ }^{3}$, Naveera Ahmed ${ }^{4}$ \\ Rozina Khattak ${ }^{5}$ \\ ${ }^{1}$ Department of Chemistry, University of Karachi, Karachi-75270, Pakistan \\ ${ }^{2}$ School of Natural Sciences, National University of Sciences and Technology, \\ Islamabad-44000, Pakistan. \\ ${ }^{3}$ Department of Food Science and Technology, University of Karachi, Karachi-75270, Pakistan \\ ${ }^{4}$ Department of Biosciences and Technology, Khawaja Fareed UEIT, Rahim Yar Khan-64200, Pakistan. \\ ${ }^{5}$ Department of Chemistry, Shaheed Benazir Bhutto Women University, Peshawar, Pakistan. \\ *Correspondence Author's email: smasood@uok.edu.pk
}

\begin{abstract}
The present review deals with the qualitative and quantitative determinations of medicinal plants from classical to advance analytical methods. Medicinal plant analysis by different analytical viz., Spectroscopy, chrmatography, computational \& spray drying methods have been reported and its essential to understand under current pandemic condition. Researchers are continuously engaged to find out the solution to overcome the problems caused by viruses like degue and COVID-19. Synthetic as well as natural remedies were applied to combat the spread of disease. Several drugs are obtained from natural resources which are utilized in controlling the disease. A piece of depth knowledge about the significance of medicinal plants towards healing, primary healthcare, and drug discovery is required using advanced technologies.
\end{abstract}

Keywords: Medicinal plants; Analytical Methods; HPLC; Spectroscopy; Spray Drying.

\section{Highlights:}

- Different analytical techniques utilized for useful component analysis served as medicine.

- Spectroscopy, HPLC, Computational and spray drying techniques were performed for separation, identification and preservation of herbal components.

\section{Introduction}

Plants are an important source for a broad range of foodstuffs that are imperative for human requirements. Plant resources are utilized for numerous functions together with wood, food, and medication (Cowan, 1999; Patwardhan et al., 2005). At present, approximately one-third of accessible medicines arrive from natural foodstuffs that have a plant source (Strohl, 2000). Currently, in pandemic condition of COVID-19 different medications were taken without consulting a physician (i.e. self medication). Self medication of analgesics, antipyretics, antitussives, antidiarrheals, calcium and vitamin supplements, anabolic steroids, sedatives, certain antibiotics, and many herbal and homeopathic remedies globally, affecting both developed and developing countries (Masood et al. 2020; Malik et al. 2020). Self medication of herbal medicine causing no more side effects as compare to rest of these medication.

Medicinal plants have shown great importance in healing, primary healthcare, and drug discovery (Fitzgeraldet al., 2019). Kadir et al. (2013) have repoted 13 different species of plants as a anti dengue agents by using their leaves, fruits and seeds (Lim, et al., 2021). Several researchers utilized different parts of plants for the treatment of COVID-19 (Lim et al., 2021; Khadka et al., 2021; Tariq et al., 2021; Adhikari et al., 2020; Nugraha et al., 2020) and found good results as shown in Table 1.

Chaachouay et al., (2021) have studied the 20 plant species which repeatedly used by herbalists of Salé Prefecture (herbal market) for the cure of COVID-19. Commonly, used plants were Eucalyptus globules Labill., Azadirachta indica , A. Juss,. and Ziziphus lotus, Lam.

In agreement with the current needs and supplies for drug manufacturing, the verification of analytical techniques or processes is the precondition for the composition of pharmacopoeial monographs development modifiable the quality testing of organic pharmaceuticals or plant origin. Consequently, it is essential to authenticate analytical methods for their proposed utilize in assessing the quality of the drug (Alekandrovna et al., 2019). The current review article deals with the qualitative and quantitative estimation of medicinal plants from classical to advance techniques. 
Table 1. Medicinal plants utilized in COVID-19 and their phytochemical activities.

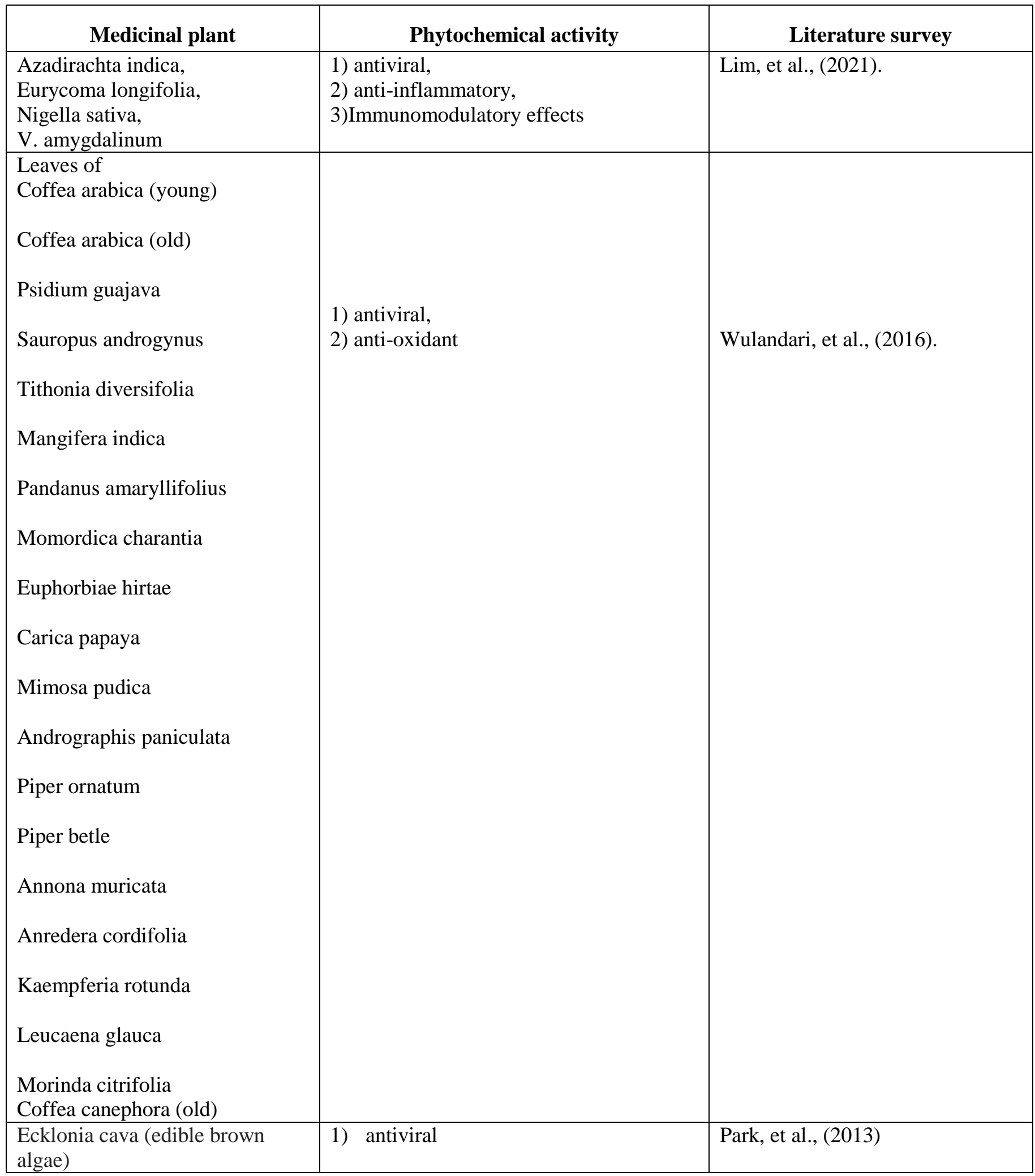

1.1 Quality control, identification, and expansion of herbal medicines (Official Pharmacopoeias) 
There are several international pharmacopeias for herbal medicines and their raw materials, such as international pharmacopeia WHO (Ph. Int, WHO) (WHO Guidelines 2009), European Pharmacopoeia Ph. Eur. British Pharmacopoeia, United States Pharmacopeia, German-Japanese, Russian (Kiseleva et al., 2010), and Chinese Pharmacopoeia. Chinese Pharmacopoeia (ChP) 2015 is a complete \& wide-ranging monograph. Consequently, the presented German-Japanese analytical methods were usually operated for the isolation of some medicinal compounds (Fitzgerald et al., 2019). Similarly, other pharmacopeias/monographs of the world covering all verities and species (raw plants, teas, slices, herbal mixtures, herbal drug mixtures, mixture herbal products, herbal collections, and oils are still utilized in approximately all conventional therapeutic system. (Hamid-Reza et al., 2013, 598; Qian et al., 2010; Yong et al., 2007; Che 2013).

\subsection{Qualitative Analysis}

Primarily, organoleptic or through physical senses method of analysis for medicinal plants were adopted during the period of the last seven decades, with the passage of scientific revolution progress of several most primitive analytical tools applied that were supporting the senses, the telescope, and microscope. These earliest analytical tools have great importance regarding the chemical, structural and atomic levels as the human perception has been broadened for sensitivity and range. Coming out of these analytical practicesin several features is equivalent to the sensory evaluation or organoleptic mixture that happens while picking the rapeutic plants by enhancing the peak of reference/arithmetical extent of freedom to get better the likelihood of suitably classifying and reviewing its quality. However, many new techniques and methods, especially the development of chromatographic and spectroscopic, have developed (Fitzgerald et al., 2019).

\section{Analytical Methods}

Analytical Methods utilized for medicinal plants are as follows;

\subsection{Spectroscopic techniques}

Extraction and segregation of solitary and multiple compounds from medicinal plants were conducted based on fundamental colorimetric determination, ultraviolet \& visible (Hardy, 1938), and IR (infrared) spectroscopy. In quantitative applications, the analysis and chemical composition of glucoside in walnuts were examined (Daglish, 1950).

Several Spectrophotometric methods have been extensively utilized for the standardization and quantitative determination of a variety of biologically active compounds such as flavonoids, fundamental oils, phenolic compounds, and tannins) (Galvão et al. 2014; Grubesić et al. 2005; Aisha et al. 2013; Bokov 2018; da Silva et al. 2015; Alekandrovna et al.2019). Essential nutrient elements were analyzed by the Indian researchers through AAS in a folk medicinal plant (Eucalyptus Oblique and Gava) (Santosh Teerthe 2018; Singh, et al. 1997).

Near-Infrared (NIR) spectroscopy is a reasonable and constructive analytical technique due to the addition of new computational software used in quality control analysis that differentiates the species. It provides quantitative information on metabolite content and isused in multivariate analysis. It also resolves the small contrast that occurs in metabolite content and also preserves sample integrity. Moreover, no sample preparation is required; as a result no need for solvents. It is a very good technique for discrimination of species and metabolites quantification. However, it is sensitive and only appropriate for sensing analytes greater than $0.1 \%$ (Fitzgerald et al. 2019). Wulandari et al. (2016) identified flavonoid content in medicinal plants by using UV- visible and NIR spectroscopy.

\subsection{Chromatographic techniques}

Paper chromatography is the classical technique that has been functional for the quality control analysis of medicinal plants (Paris and Viejo, 1955; Jaminet, et al. 1959; Hills and Rodwell, et al. 1951; Dybing et al., 1954; Krejci, 1958).

HPLC is a broadly used analytical technique, particularly in herbal products. Its components that performed the separation are entirely dependent upon discriminating attraction to the solid supports (stationary) and liquid (mobile) phases. It has been widely used in the analysis of the same compounds of complex mixtures. Due to its high-resolution technique, the conception of distinctive"fingerprints" has been build up for therapeutic plants and herbal-based products to support recognition and verification. Medicinal plant products, which are of the same type, from almost 40 separate manufacturers exhibited the differentiation under HPLC. Moreover, it also separates the nine marker chemical compounds (Fitzgerald et al., 2019). Numbers of research works have been published for the analysis of medicinal plants by the high-performance liquid chromatography, as few articles are summarized in the table below (Table 2).

Table 2. HPLC data of different compounds extracted from plants sources. 


\begin{tabular}{|c|c|c|c|c|c|c|c|}
\hline Compound & Extract & Column & Mobile phase & $\begin{array}{l}\text { Wavelengt } \\
\text { h } \\
(\mathrm{nm})\end{array}$ & Detector & $\begin{array}{l}\text { Flow } \\
\text { Rate } \\
\text { mL/min }\end{array}$ & Ref. \\
\hline $\begin{array}{l}\text { Flavonoids } \\
\text { Biophenols \& Phenols }\end{array}$ & $\begin{array}{l}\text { Olea } \\
\text { europaea } \mathrm{L} \\
\text { (olives) }\end{array}$ & $\begin{array}{l}\text { RP- } C_{18} \quad \text { Bakerbond } \\
\text { column }(250 \times 4.6 \mathrm{~mm}, 5 \\
\mu \mathrm{m}), \text { connected with }(50 \times \\
4 \mathrm{~mm}) \text { precolumn }\end{array}$ & $\begin{array}{l}\text { Solvent A: } \\
\text { Water:Acetic acid, (98: } \\
\text { 2) pH } 3.1 \\
\text { Solvent B: } \\
\text { methanol }\end{array}$ & $230 \& 278$ & Diode Array & 1 & $\begin{array}{l}\text { Bianco, \& } \\
\text { Uccella, } \\
(2000)\end{array}$ \\
\hline $\begin{array}{l}\text { Flavonoids } \\
\text { (Antioxidants) }\end{array}$ & $\begin{array}{l}\text { Thymus } \\
\text { vulgaris } \mathrm{L} .\end{array}$ & $\begin{array}{l}\text { Alltima } \mathrm{C}_{18} \mathrm{RP}, \text { column } \\
(250 \times 4.6 \mathrm{~mm}, 5 \mu \mathrm{m})\end{array}$ & $\begin{array}{l}\text { Solvent A: } \\
\text { Water:Acetonitrile }(3: 1) \\
\text { acidified with glacial } \\
\text { acetic acid }(0.25 \%) \\
\text { Solvent B: } \\
\text { Acetonitrile acidified } \\
\text { with glacial acetic acid } \\
(0.25 \%)\end{array}$ & $210-450$ & Flourescence & 0.85 & $\begin{array}{l}\text { Dapkevic } \\
\text { ius, et } \\
\text { al. }(2001)\end{array}$ \\
\hline $\begin{array}{l}\text { Polyphenols } \\
\text { (procyanidins) }\end{array}$ & $\begin{array}{l}\text { Vitis } \\
\text { vinifera }\end{array}$ & $\begin{array}{l}\text { LiChrospher } \mathrm{RP}^{-\mathrm{C}_{18}} \\
\text { column }(250 \times 4 \mathrm{~mm}, \quad 5 \\
\mu \mathrm{m}) \text { connected with guard } \\
\text { column }(10 \times 4 \mathrm{~mm})\end{array}$ & $\begin{array}{l}\text { Solvent A: } \\
1 \mathrm{~L} \quad \text { water } \quad+1 \mathrm{~mL} 85 \% \\
\mathrm{H}_{3} \mathrm{PO}_{4} \\
\text { Solvent B: } \\
\text { methanol; }\end{array}$ & 280 & UV-Vis & 1 & $\begin{array}{l}\text { Kennedy, } \\
\text { et al. } \\
(2000)\end{array}$ \\
\hline $\begin{array}{l}\text { Catechins \& } \\
\text { Epicatechins }\end{array}$ & Crataegus & $\begin{array}{lr}\text { LiChrosorb } & \text { RP-18 } \\
\text { column (250 } \times & 4 \mathrm{~mm}, \\
5 \mu \mathrm{m}) \text { connected } & \text { with } \\
\text { guard column } & (10 \times 4 \\
\mathrm{mm}) & \end{array}$ & $\begin{array}{l}\text { Solvent A: Methanol } \\
\text { Solvent B: } 0.5 \% \\
o \text {-phosphoric acid in } \\
\text { water }\end{array}$ & $280 \& 220$ & - & 1 & $\begin{array}{l}\text { Rohr, et } \\
\text { al. } \\
\text { (1999) }\end{array}$ \\
\hline Isosteroidal alkaloids & Fritillaria & $\begin{array}{l}\text { Nova-Pak } \mathrm{C}_{18}-\mathrm{RP} \\
\text { column }(150 \times 3.9 \mathrm{~mm}, 4 \\
\mu \mathrm{m})\end{array}$ & $\begin{array}{l}\text { Methanol containing } \\
0.2 \% \text { diethylamine, }\end{array}$ & $224 \mathrm{~nm}$ & UV Detector & 1 & $\begin{array}{l}\text { Lin, et al. } \\
(2001)\end{array}$ \\
\hline $\begin{array}{l}\text { Coumarins } \\
\text { benzopyrones })\end{array}$ & $\begin{array}{l}\text { Citrus } \\
\text { aurantifoli } \\
a\end{array}$ & $\begin{array}{l}\text { Normal phase } \mu \text { Porasil } \\
(300 \times 3.9 \mathrm{~mm}, \quad 10 \mu \mathrm{m}) \\
\text { column OR } \\
\text { Nova-Pak } \mathrm{C}_{18} \text { column }(5 \\
\mu \mathrm{m})\end{array}$ & $\begin{array}{l}\text { Ethyl acetate : hexane } \\
(1: 4, \mathrm{v} / \mathrm{v}) \\
\text { OR } \\
\text { Solvent A: } \\
\text { Water:methanol } \quad(8: 2, \\
\text { v/v }) \\
\text { Solvent B: } \\
\text { Water:acetonitrile }(1: 1, \\
\text { v/v }) \\
\end{array}$ & $\begin{array}{l}335 \text { and } 310 \\
\mathrm{~nm}\end{array}$ & Fluorescence & 1 & $\begin{array}{l}\text { Thompso } \\
\text { n, \& } \\
\text { Brown, } \\
(1984)\end{array}$ \\
\hline Coumarins & $\begin{array}{l}\text { Archangeli } \\
\text { ca } \\
\text { officinalis }\end{array}$ & $\begin{array}{l}\text { RP-18 column }(250 \times 4.6 \\
\mathrm{mm}, 5 \mu \mathrm{m})\end{array}$ & $\begin{array}{l}\text { Methanol:water with } \\
\text { different ratio } \\
(8: 2 ; 7: 3 ; 6: 4, \mathrm{v} / \mathrm{v})\end{array}$ & 254 & UV-Vis & 1 & $\begin{array}{l}\text { Hawryl, e } \\
\text { t al. } \\
(2000)\end{array}$ \\
\hline Alkamides & $\begin{array}{l}\text { E. } \\
\text { purpurea, } \\
\text { E. } \\
\text { pallida and } \\
\text { E. } \\
\text { angustifoli } \\
\text { a }\end{array}$ & $\begin{array}{l}\text { Hibar }(125 \times 4 \mathrm{~mm}, 5 \mu \mathrm{m}) \\
\text { column, with LiChrospher } \\
100 \mathrm{CH}-18 \\
\text { LiChroCART precolumn } \\
(4 \times 4 \mathrm{~mm}, 5 \mu \mathrm{m}) \text { with } \\
\text { LiChrospher } 100-\mathrm{CH} \text {; }\end{array}$ & $\begin{array}{l}\text { Water: Acetonitrile } \\
\text { Gradient elution from } 40 \text { - } \\
80 \% \text { within } 30 \mathrm{~min} \text {, }\end{array}$ & $210 \& 254$ & UV-Vis & 1 & $\begin{array}{l}\text { Bauer, \& } \\
\text { Remiger, } \\
(1989)\end{array}$ \\
\hline Alkamides & $\begin{array}{l}E . \\
\text { Pallida (As } \\
\text { teraceae) }\end{array}$ & $\begin{array}{l}\text { RP-C18, silica gel column } \\
(7.5 \mathrm{~cm}, 3 \mu \mathrm{m}),\end{array}$ & $\begin{array}{l}\text { Acetonitrile:water } \\
(6: 4, \mathrm{v} / \mathrm{v})\end{array}$ & $210 \& 260$ & UV detection & 1 & $\begin{array}{l}\text { Binns, et } \\
\text { al. } \\
(2001)\end{array}$ \\
\hline Polyacetylenes & $\begin{array}{l}\text { Cicuta } \\
\text { virosa } \mathrm{L} . \\
\text { (Apiaceae, } \\
\text { Apioideae) }\end{array}$ & $\begin{array}{l}\text { Spherisorb } \quad \text { S5 } \quad \text { ODS2 } \\
\text { column }(290 \times 4 \mathrm{~mm})\end{array}$ & $\begin{array}{l}\text { Methanol:Aqueous } \\
\text { buffer } 60-100 \% \text {, Buffer } \\
\text { (o-phosphoric acid } 0.015 \\
\text { M, tetrabutylammonium }\end{array}$ & 230 & $\begin{array}{l}\text { Diode array } \\
\text { detector }\end{array}$ & 1 & $\begin{array}{l}\text { Cimpan, } \\
\text { \& Gocan, } \\
(2002) ; \\
\text { Wittstock }\end{array}$ \\
\hline
\end{tabular}




\begin{tabular}{|c|c|c|c|c|c|c|c|}
\hline & & & $\begin{array}{ll}\begin{array}{l}\text { hydroxide } \\
\text { pH=3) }\end{array} & 0.0015 \mathrm{M}, \\
\end{array}$ & & & & $\begin{array}{l}\text {, et al. } \\
\text { (1995). }\end{array}$ \\
\hline Miscelaneous & $\begin{array}{l}\text { Gastrodia } \\
\text { elata } \\
\text { Blume (Orc } \\
\text { hidaceae) }\end{array}$ & $\begin{array}{l}\text { ODS Zorbax } \\
\text { SB-C } 18 \text { column }(250 \times 4.5 \\
\mathrm{mm}, 5 \mu \mathrm{m})\end{array}$ & $\begin{array}{l}\text { Methanol:water:isopropy } \\
1 \text { alcohol } \\
(35: 55: 10, \mathrm{v} / \mathrm{v})\end{array}$ & 270 & - & 0.4 & $\begin{array}{l}\text { Li, et } \\
\text { al. (2001) }\end{array}$ \\
\hline $\begin{array}{l}\text { Soybean (seeds \& } \\
\text { roots) }\end{array}$ & $\begin{array}{l}\text { Phytoalexi } \\
\text { ns }\end{array}$ & $\begin{array}{l}\text { For RP-HPLC } \\
\text { Nova-Pak } \quad \mathrm{C}_{18} \text { column } \\
(150 \times 3.9 \mathrm{~mm}, 4 \mu \mathrm{m})\end{array}$ & $\begin{array}{l}\text { Solvent A: } \\
\text { Methanol; } \\
\text { Solvent B: } \\
\text { Aqueous buffer } 0.01 \mathrm{M} \\
\mathrm{KH}_{2} \mathrm{PO}_{4}(\mathrm{pH} \quad 2.4 \quad \text { with } \\
\mathrm{HCl} \text { ) and } 0.1 \% \quad \mathrm{Et}_{3} \mathrm{~N} \\
\text { (final pH about } 2.46 \text { ) }\end{array}$ & 220 & - & 1 & $\begin{array}{l}\text { Faghihi, e } \\
\text { t al. } \\
(2001)\end{array}$ \\
\hline $\begin{array}{l}\text { Soybean (seeds \& } \\
\text { roots) }\end{array}$ & $\begin{array}{l}\text { Phytoalexi } \\
\text { ns }\end{array}$ & $\begin{array}{l}\text { For NP-HPLC } \\
\text { Hypersil Si column }(150 \times \\
4.6 \mathrm{~mm}, 5 \mu \mathrm{m})\end{array}$ & Hexane & 254 & - & 0.8 & $\begin{array}{l}\text { Faghihi, e } \\
\mathrm{t} \text { al. } \\
(2001)\end{array}$ \\
\hline Phytoestrogens & $\begin{array}{l}\text { H. } \\
\text { lupulus } \mathrm{L} .\end{array}$ & $\begin{array}{l}\text { Alltima RP } \mathrm{C}_{18} \text { column } \\
(250 \times 4.6 \mathrm{~mm}, 5 \mu \mathrm{m})\end{array}$ & $\begin{array}{l}\text { Solvent A: } \\
\text { Formic acid in water } \\
\text { Solvent B: } \\
\text { Acetonitrile }\end{array}$ & 280 & - & 0.9 & $\begin{array}{l}\text { Rong, et } \\
\text { al. } \\
\text { (2000) }\end{array}$ \\
\hline
\end{tabular}

This technique is an inexpensive and simple method in which a small amount of sample is needed without an advanced sample preparation method. Although it is a sensitive technique, it is best to detect contaminants. In performing HPTLC, thin layer chromatographic plates (as stationary phase) different solvent systems are required as a mobile phase. The sample was added by spraying it onto the plate, which then formed a band of the compound in a more reproducible and precise way. Moreover, the $\mathrm{R}_{\mathrm{f}}$ factors (retention) of each compound are further testable (Fitzgerald et al., 2019). Senguttuvan and Subramaniam (2016) studied the methanolic extracts of leaf and roots of Hypochaeris radicata and thus validates its medicinal usage.

GC is utilized for the analytical determination of those compounds which are highly volatile. Previously, the methods that are employed for the compilation and manufacturing of these compounds werecompressing, steaming, and decontamination of herb-based materials. However, there are difficulties in introducing the sample into a gas stream, the intrinsic unsteadiness of volatile constituents, fatalities, and poor recovery of these substances. Therefore, microextraction techniques are beneficial for these techniques. Extraction techniques based on the needleare better because of their mechanization, simplicity of crossing point to further instruments furthermore, their compatibility with trimness (Steinmann, et al., 2011; Fitzgerald et al., 2019). Similarly, medicinal plant morphology and chemical composition of the volatile oil of various domestic species of china were successfully analyzed by the GC techniques (Zou, 2009).

\subsection{Computational approaches}

The number of computational approaches for the analysis of a variety of analytes takes part in the important function in computer-aided drug design (Jorgensen, 2004). Sharma and Sakar (Sharma \& Sarkar, 2013) presented a quick and proficient method for the drug design and discovery of medicinal plants . Considering, computational drug discovery techniques Rallabandi et al., (2020) suggested that in future research should focus more on using computational biology to design new and more potent drugs for therapy with a better understanding of drug and receptor interaction.

\subsection{Spray Drying Technique}

Drying procedures are the most fundamental, quick, uncomplicated and universal methods that allow the rapid preservation of medicinal plant extracts and medicinal plant products like phytotherapeutics or phytomedicines and phytopharmaceuticals. In current era, many factors must taken into an account in order to apply drying methods such as level of production, quality standards of medicinal plant products and technology used. For inhibiting enzymatic activity, restrict microbial growth or increased shelf life by decreasing water content, drying technique also contributes in reduction of herbal plant volume with ease in transportation and storage. 
Transformation of herbsbased raw materials into a medicinal product, appropriate for consumer andcurativefunctions, needs specialized operational processing and obviously complex in nature. Numerousmethods can be functional for this purpose,like freeze and spouted bed drying, fluidizedbed and spray drying. The most common ventilation or exposure to air technique used in the phytopharmaceuticalindustries for production of powdered medicinal plant products is spray drying that offers operationalelasticity, applicability for sensitiveto heatmaterials, in addition to an effective charge. Spray drying is a procedureby means of a liquid can convert into desiccated particles of micron size by a burning drying gasmedium. The spray-drying progressions diminish water activity of products, slow downthe microbial deprivationand broaden the product's shelf life (Vardin, and Yasar, 2012; Vladić, et al., 2016).

Chemical, physical and microbiological factors contribute to optimizing the spray drying procedurefor the stability of the medicinal herbs. These parameters depend on the humiditylevelof tissues at harvesting time, the plant components utilized, and the temperature most excellentapposite for conservation of the required constituents. This happened without compromising the quality parameter of generic constituents of medicinal plants. The rapid moisture reduction can be made by spray-drying via controlling humidity, flow rate, and temperature. The spray drying technique has been extensively utilized to acquireda larger concentration of biologically active ingredients in dry form. The literature overview of medicinal plants and their phytochemical activity is shown in Table 3.

Table 3. Medicinal plants and their phytochemical activities.

\begin{tabular}{|c|c|c|}
\hline Medicinal plant & Phytochemical activity & Literature survey \\
\hline Peppermint (Mentha piperita) & Antioxidant activity & Baranauskienè, et al. (2007) \\
\hline Chamomile (Matricia chamomilla), & Prevent insomnia, antioxidanrt activity & Adib-Hajbaghery, et al. (2017). \\
\hline $\begin{array}{l}\text { Wild thyme or creeping thyme } \\
\text { (Thymus serpyllum) }\end{array}$ & Antiobacterial activity & Shafique, et al. (2020). \\
\hline $\begin{array}{c}\text { Mountain germander (Teucrium } \\
\text { montanum }\end{array}$ & Antioxidant activity & Vidović, et al. (2014). \\
\hline Winter savory (Satureja montana), & Antioxidant activity & Vidović, et al.(2014). \\
\hline $\begin{array}{c}\text { Common yarrow (Achillea } \\
\text { millefolium), }\end{array}$ & Antioxidant activity & Vladić, et al. (2016) \\
\hline Common sage (Salvia officinalis), & Antioxidant activity & Alaşalvar, \& Çam, (2019). \\
\hline Lemon balm (Melissa officinalis), & Antioxidant activity & Tülek, et al.(2020). \\
\hline $\begin{array}{c}\text { Centaurea (Erythraea centaurium } \\
\text { Pers.) }\end{array}$ & Anti inflammatory & Vidović, et al.(2014). \\
\hline Rosmarinus officinalis (Rosemery) & $\begin{array}{c}\text { Antispasmodic in renal colic and } \\
\text { dysmenorrheal, in relieving respiratory } \\
\text { disorders, choleretic, hepatoprotective and } \\
\text { antitumerogenic activity, antioxidant activity }\end{array}$ & Souza, et al. (2008). \\
\hline Marrubium vulgare & $\begin{array}{l}\text { Antioxidant, anti-inflammatory and } \\
\text { vasorelaxant effects, antimicrobial activity }\end{array}$ & Gavarić, et al.(2019). \\
\hline Passiflora alata, and & $\begin{array}{l}\text { Sedatives, hypnotics, tranquilizers, and anti- } \\
\text { inflammatory, reduction of the hyperactivity } \\
\text { in children,antispasmodics, and as pain } \\
\text { relievers }\end{array}$ & Oliveira, et al. (2006). \\
\hline Bauhinia forficata, & Hypoglycemic, depurative, and diuretic & Oliveira, et al. (2006). \\
\hline Maytenus ilicifolia & $\begin{array}{c}\text { Treatment of ulcers, indigestion, chronic } \\
\text { gastritis, and dyspepsia }\end{array}$ & Oliveira, et al. (2006). \\
\hline Bidens pilosa $\mathrm{L}$. & $\begin{array}{l}\text { Antimalaric, hepatoprotector, antimicrobial } \\
\text { and antitumoral agent }\end{array}$ & Cortés-Rojas, et al. (2015). \\
\hline $\begin{array}{c}\text { Rhamnus purshiana (Cáscara sagrada) } \\
\text { e }\end{array}$ & Natural laxative action & Gallo,et al. (2011). \\
\hline Soyabean extract & Antioxidant activity & Georgetti, et al. (2008). \\
\hline Eugenia dysenterica & Antioxidant activity & Couto,et al. (2011). \\
\hline
\end{tabular}




\begin{tabular}{|c|c|c|}
\hline Morinda citrifolia $\mathrm{L}$. & Antibiotic and antioxidant property & Krishnaiah,et al. (2012) \\
\hline Orthosiphon stamineus & $\begin{array}{l}\text { Antidiabetic, antiangiogenic and } \\
\text { antiproliferative properties }\end{array}$ & Pang, et al. (2014) \\
\hline Phyllanthus niruri e & $\begin{array}{c}\text { Antimicrobial, anti inflammatory and } \\
\text { analgesic properties }\end{array}$ & Gimbun,et al. (2018). \\
\hline Curcumin extract & $\begin{array}{l}\text { Antioxidant, antiseptic, antimicrobial and } \\
\text { antitumoral substance }\end{array}$ & Araújo, et al. (2010 \\
\hline Orange peel & Antioxidant activity & Shofinita\& Langrish (2014). \\
\hline Murraya koenigii (Linn) curry leaves & $\begin{array}{l}\text { Anti-oxidative, cytotoxic, antimicrobial, } \\
\text { antibacterial, antifungal, anti-inflammatory, } \\
\text { antiulcer, positive inotropic and } \\
\text { anticholesterolemic activities }\end{array}$ & Sablania \& Bosco (2018). \\
\hline Averrhoa carambola pomace & Antioxidant activity & Saikia,et al. (2015) \\
\hline Propolis extract & Antioxidant property & \\
\hline & & Marquele, et al. (2006) \\
\hline Grapes & $\begin{array}{c}\text { Cardioprotective effect, anti-cancer, anti- } \\
\text { diabetes, antimicrobial, } \\
\text { And anti-inflammatory properties } \\
\end{array}$ & Kuck, et al. (2017). \\
\hline Coffee & $\begin{array}{l}\text { Antioxidant activity, antimicrobial activity, } \\
\text { antidiabetic, anti inflammatory }\end{array}$ & Ballesteros, et al.(2017). \\
\hline Saffron & Antioxidant activity & Khazaei,et al. (2014). \\
\hline Acerola (Malpighia emarginata & Antioxidant activity & Rezende,et al. (2018). \\
\hline Mint & Antioxidant activity & Sarkar, et al.(2013) \\
\hline Flax seed & Antioxidant activity & Liu, et al. (2010). \\
\hline Clove & $\begin{array}{c}\text { Antiofungal, intiinflammatory and } \\
\text { antibacterial activity }\end{array}$ & Chatterjee, \& Bhattacharjee, (2013). \\
\hline Coriander & Antimicrobial activity & Dima, et al. (2014). \\
\hline Cinnamon & Antioxidant and antibacterial activity & Shahidi \& Molaveisi, (2020) \\
\hline Habanero chilli & Antioxidant and antibacterial activity & $\begin{array}{c}\text { Domínguez-Cañedo, \& Beristain-Guevara, } \\
(2011)\end{array}$ \\
\hline $\begin{array}{l}\text { Psidium guajava L. } \\
\text { (Yellow guava) }\end{array}$ & $\begin{array}{l}\text { Antioxidant and antimicrobial activity, anti- } \\
\text { viral, anti-inflammatory, anti-plaque and anti- } \\
\text { mutagenic activities. }\end{array}$ & Mahfuzul Hoque, et al. (2007). \\
\hline P. Boldus & $\begin{array}{l}\text { Cholagogue, liver } \\
\text { Stimulant }\end{array}$ & Gallo,et al.(2015). \\
\hline R. Purshiana & $\begin{array}{l}\text { Laxative for short-term } \\
\text { Treatment of occasional } \\
\text { Constipation }\end{array}$ & Gallo, et al.(2015). \\
\hline C. Asiatica & $\begin{array}{l}\text { Venotonic } \\
\text { Anti-cellulite }\end{array}$ & Gallo,et al. (2015). \\
\hline V. Officinalis M & $\begin{array}{l}\text { Mild sedative and } \\
\text { Sleep-promoting agent }\end{array}$ & Gallo,et al. (2015). \\
\hline H. Virginiana & $\begin{array}{c}\text { Venotonic for the } \\
\text { Treatment varicose } \\
\text { Veins }\end{array}$ & Gallo,et al. (2015). \\
\hline H. Perforatum & $\begin{array}{l}\text { Treatment of mild and } \\
\text { Moderate depressive } \\
\text { Episodes }\end{array}$ & Gallo, et al. (2015). \\
\hline C. Scolymus & $\begin{array}{l}\text { Adjunct treatment } \\
\text { Of mild to moderate } \\
\text { Hypercholesterolaemia, } \\
\text { Antioxidant }\end{array}$ & Gallo,et al.(2015). \\
\hline
\end{tabular}


Pomegranate (Punica Granatum L. $\quad$ Anti-atherogenic effects and anti-oxidative properties
Vardin, \& Yasar, (2012).

\section{Acknowledgment}

The authors are grateful to the Dean Faculty of Science, the University of Karachi, for providing the grant.

\section{Conflict of interest}

It is declared that there is no conflict of interest among the authors.

\section{References}

Adhikari B., Marasini B.P., Rayamajhee B., et al. Potential roles of medicinal plants for the treatment of viral diseases focusing on COVID-19: A review. Phytotherapy Research. 2020;1-15.

Adib-Hajbaghery, M., \& Mousavi, S. N. (2017). The effects of chamomile extract on sleep quality among elderly people: A clinical trial. Complem. therapies Med., 35, 109-114.

Aisha A.F, Abu-Salah K.M, Ismail Z, Majid A.M. (2013). Determination of total xanthones in Garcinia mangostana fruit rind extracts by ultraviolet (UV) spectrophotometry. J Med Plants Res., 7, 29-35.

Alaşalvar, H., \& Çam, M. (2019). Process for production of ready to drink iced teas from sage (Salvia officinalis L.) and linden (Tilia cordata): pressurized hot water extraction and spray drying. Food science and biotechnology, 28(3), 779-785.

Araújo, R. R., Teixeira, C. C. C., \& Freitas, L. A. P. (2010). The preparation of ternary solid dispersions of an herbal drug via spray drying of liquid feed. Drying Technology, 28(3), 412-421.

Ballesteros, L. F., Ramirez, M. J., Orrego, C. E., Teixeira, J. A., \& Mussatto, S. I. (2017). Encapsulation of antioxidant phenolic compounds extracted from spent coffee grounds by freeze-drying and spray-drying using different coating materials. Food chemistry, 237, 623-631.

Baranauskienė, R., Bylaite, E., Žukauskaitė, J., \& Venskutonis, R. P. (2007). Flavor retention of peppermint (Mentha piperita L.) essential oil spray-dried in modified starches during encapsulation and storage. J. Agricult. Food Chem., 55(8), 3027-3036.

Bauer, R. and Remiger, P. (1989). TLC and HPLC Analysis of Alkamides in Echinacea Drug. Planta Medica, 55, 367371.

Bauer, R., Reimiger, P. and Wagner, H. (1988). Echinacea Vergleichende DC-und HPLC-Analyse der Herb-Drogen von Echinacea purpurea, E. pallida und E. angustifolia. Dtsch.. Apoth. Ztg., 128, 174-180.

Bianco, A. and Uccella, N. (2000). Biophenolic Components of Olives. Food Res. Intl., 33, 475-485.

Binns, S. E., Inparajah, I., Baum, B. R. and Arnason, J. T. (2001). Methyl Jasmonate Increases Reported Alkamides and Ketoalkene/ynes in Echinacea Pallida (Asteraceae). Phytochemistry. 57, 417-420.

Bokov D.O. (2018). Standardization of snowdrop (Galanthus L.) herbal pharmaceutical substances by ultravioletspectrophotometry. Asian J. Pharm. Clin. Res., 11, 207-11.

Chaachouay, N., Douira, A., Zidane, L. (2021). COVID-19, prevention and treatment with herbal medicine in the herbal markets of Salé Prefecture, North-Western Morocco, European J. Integrative Med., 42, 101285 (1-10).

Chatterjee, D., \& Bhattacharjee, P. (2013). Comparative evaluation of the antioxidant efficacy of encapsulated and unencapsulated eugenol-rich clove extracts in soybean oil: Shelf-life and frying stability of soybean oil. J. Food Engineering, 117(4), 545-550.

Che C.T, Wang Z.J, Chow M..S, Lam C.W. (2013). Herb-herb combination for therapeutic enhancement and advancement: Theory, practice and future perspectives. Molecules, 18, 5125-41. 
Cimpan, G. and Gocan, S. (2002) Analysis of medicinal plants by HPLC: Recent approaches. J. Liq. Chromatogr. Rel. Technol., 25, (13-15), 2225-2292.

Cortés-Rojas, D. F., Souza, C. R. F., \& Oliveira, W. P. (2015). Optimization of spray drying conditions for production of Bidens pilosa L. dried extract. Chemical Engineering Research and Design, 93, 366-376.

Couto, R. O., Araújo, R. R., Tacon, L. A., Conceição, E. C., Bara, M. T. F., Paula, J. R., \& Freitas, L. A. P. (2011). Development of a phytopharmaceutical intermediate product via spray drying. Drying Technology, 29(6), 709-718.

Cowan M.M. (1999). Plant products as antimicrobial agents. Clin Microbiol Rev., 12, 564-82.

da Silva L.A, Pezzini B.R, Soares L. (2015). Spectrophotometric determination of the total flavonoid content in Ocimum basilicum L.(Lamiaceae) leaves. Pharmacogn Mag., 11, 96-101.

Daglish, C. (1950). The isolation and identification of a hydrojuglone glycoside occurring in the walnut. Biochem. J. 47 (4), 452.

Dapkevicius, A., Beek, T. A.V. and Niederlander, H.A. G. (2001). Evaluation and Comparison of Two Improved Techniques for the On-Line Detection of Antioxidants in Liquid Chromatography Eluates. J. Chromatogr. A, 912(01), 7382.

Dima, C., Cotarlet, M., Tiberius, B., Bahrim, G., Alexe, P., \& Dima, S. (2014). Encapsulation of coriander essential oil in beta-cyclodextrin: antioxidant and antimicrobial properties evaluation. Romanian Biotechnological Letters, 19(2), 91289140 .

Domínguez-Cañedo, I. L., \& Beristain-Guevara, C. I. (2011). Microencapsulation of Habanero chilli (Capsicum chinense) oleoresin in $\beta$-ciclodextrin and antioxidant activity during storage. European Drying Conference-Euro Drying. Palma. Balearic Island, Spain, 26-28.

Dybing, F., Dybing, O., Jensen, K. B. (1954). Detection of scilliroside in organic material. Acta Pharmacol. Toxicol. 10 (2), 93-100.

Faghihi, J., Jiang, X., Vierling, R., Goldman, S., Sharfstein, S., Sarver, J. and Erhardt, P. (2001). Reproducibility of the High-Performance Liquid Chromatographic Fingerprints Obtained from Two Soybean Cultivars and a Selected Progeny. J. Chromatogr. A, 915, 61-74.

Fitzgerald, M., Heinrich M., and Booker A. (2019). Medicinal Plant Analysis: A Historical and Regional Discussion of Emergent Complex Techniques. Front Pharmacol. 10, 1480.

Gallo, L., Llabot, J. M., Allemandi, D., Bucalá, V., \& Piña, J. (2011). Influence of spray-drying operating conditions on Rhamnus purshiana (Cáscara sagrada) extract powder physical properties. Powder Technology, 208(1), 205-214.

Gallo, L., Ramírez-Rigo, M. V., Piña, J., \& Bucalá, V. (2015). A comparative study of spray-dried medicinal plant aqueous extracts. Drying performance and product quality. Chem. Eng. Res. Design, 104, 681-694.

Galvão M.A, Ferreira M.R, Nunes B.M, Santana A.S, Randau K.P, Soares L.A. Validation of a spectrophotometric methodology for the quantification of polysaccharides from roots of Operculina macrocarpa (jalapa) Rev Bras Farmacogn. 2014;24:683-90.

Gavarić, A., Vladić, J., Ambrus, R., Jokić, S., Szabó-Révész, P., Tomić, M., ... \& Vidović, S. (2019). Spray drying of a subcritical extract using Marrubium vulgare as a method of choice for obtaining high quality powder. Pharmaceutics, 11(10), 523.

Georgetti, S. R., Casagrande, R., Souza, C. R. F., Oliveira, W. P., \& Fonseca, M. J. V. (2008). Spray drying of the soybean extract: effects on chemical properties and antioxidant activity. LWT-Food Science and Technology, 41(8), 1521-1527.

Gimbun, J., Nguang, S. L., Pang, S. F., Yeong, Y. L., Kee, K. L., \& Chin, S. C. (2018). Assessment of phenolic compounds stability and retention during spray drying of phyllanthus niruri extracts. Industrial \& Engineering Chemistry Research, 58(2), 752-761. 
Grubesić RJ, Vuković J, Kremer D, Vladimir-Knezević S. (2005). Spectrophotometric method for polyphenols analysis: Prevalidation and application on Plantago L. species. J Pharm Biomed Anal. , 39, 837-42.

Hamid-Reza, A., Scherer, U., Kaehlig, H., Hettich, T., Schlotterbeck, G., Reich, E., Krenn L (2013). Combination of bioautography with HPTLC-MS/NMR: a fast identification of acetylcholinesterase inhibitors from galbanum. Phytochem. Anal. 24 (4), 395-400.

Hardy, A. C. (1938). History of the design of the recording spectrophotometer. J. Opt. Soc. Am., 28 (10), 360-364.

Hawryl, M.A., Soczewinski, E. and Dzido, T. H. (2000). Separation of Coumarins from Archangelica officinalis in HighPerformance Liquid Chromatography and Thin-Layer Chromatography Systems. J. Chromatogr. A, 886, 75-81.

Hills, K. L., Rodwell, C. N. (1951). Variation in the alkaloids of clones of northern Duboisia myoporoides R. Br. Aust. J. Biol. Sci. 4 (4), 486-499.

Jaminet, F. (1959). Comparative study of planimetric and densitometric methods on quantitative paper chromatography. Application to the determination of the alkaloids and the amines of Genista (Sarothamnus scoparius L.). Pharm. Acta Helvetiae 34, 571-584.

Jorge, R. M., Leite, J. P. V., Oliveira, A. B., \& Tagliati, C. A. (2004). Evaluation of antinociceptive, anti-inflammatory and antiulcerogenic activities of Maytenus ilicifolia. J. Ethnopharmacology, 94(1), 93-100.

Jorgensen W.L. (2004). The many roles of computation in drug discovery. Science 303, 1813-1818.

Kadir, S. L.A., Yaakob, H., \& Zulkifli, R.M. (2013). Potential anti-dengue medicinal plants: a review. J. Nat. Med., 67(4), 677-689.

Kennedy, J. A., Matthews, M.A. and Waterhouse, A. L. (2000). Changes in Grape Seed Polyphenols During Fruit Ripening. Phytochemistry, 55, 77-85.

Khadka, D., Dhamala, M.K., Li, F., Aryal, P.C., Magar, P.R., Bhatta, S., Thakur, M.S., Basnet, A., Cui, D., \& Shi, S. (2021). The use of medicinal plants to prevent COVID-19 in Nepal. J. Ethnobio. Ethnomed., 17, 26.

Khan, T., Khan, M. A., Mashwani, Z., Ullah, N., Nadhman, A.( 2021). Therapeutic potential of medicinal plants against COVID-19: The role of antiviral medicinal metabolites. Biocat. Agricul. Biotech., 31, 101890 (1-18).

Khazaei, K. M., Jafari, S. M., Ghorbani, M., \& Kakhki, A. H. (2014). Application of maltodextrin and gum Arabic in microencapsulation of saffron petal's anthocyanins and evaluating their storage stability and color. Carbohydrate polymers, $105,57-62$.

Kiseleva T.L, Smirnova Y.A, Blinkov I.L, Dronova M.A, Tsvetaeva E.V. (2010). Brief Encyclopedia of Modern Herbal Medicine with the Basics of Homeopathy: A Reference Book of a Practitioner. Moscow: Publishing House of the Professional Association of Naturotherapists;.

Krejci, Z. (1958). Hemp (Cannabis sativa) antibiotic drugs. II. Method \& results of bacteriological experiments \& preliminary clinical experience. Die Pharmazie. 13 (3), 155-166.

Krishnaiah, D., Sarbatly, R., \& Nithyanandam, R. (2012). Microencapsulation of Morinda citrifolia L. extract by spraydrying. Chemical engineering research and design, 90(5), 622-632.

Kuck, L. S., Wesolowski, J. L., \& Noreña, C. P. Z. (2017). Effect of temperature and relative humidity on stability following simulated gastro-intestinal digestion of microcapsules of Bordo grape skin phenolic extract produced with different carrier agents. Food Chem., 230, 257-264.

Li, H.-X., Ding, M.-Y., Lv, K.n, Wei, Y. \& Yu, J.-Y. (2001). Identification and Determination of the Active Compounds in Gastrodia elata Blume by HPLC. J. Liq. Chromatogr. Rel. Technol., 24(4), 579-588. 
Lim, S.Y.M., Chieng, J.Y. \& Pan, Y. (2021). Recent insights on anti-dengue virus (DENV) medicinal plants: review on invitro, invivo and insilico discoveries, All Life, 14(1), 1-33.

Lim, X.Y., The, B.P., Tan, T.Y.C. (2021). Medicinal Plants in COVID-19: Potential and Limitations. Front. Pharmacol., 12:611408 (1-8).

Lin, G., Li, P., Li, S.-L. and Chan, S.-W. (2001). Chromatographic Analysis of Fritillaria Isosteroidal Alkaloids, the Active Ingredients of Beimu, the Antitussive Traditional Chinese Medicinal Herb. J. Chromatogr. A, 935(1-2), 321-338.

Liu, S., Low, N. H., \& Nickerson, M. T. (2010). Entrapment of flaxseed oil within gelatin-gum arabic capsules. J. Am. Oil Chemists' Soc., 87(7), 809-815.

Mahfuzul Hoque, M. D., Bari, M. L., Inatsu, Y., Juneja, V. K., \& Kawamoto, S. (2007). Antibacterial activity of guava (Psidium guajava L.) and neem (Azadirachta indica A. Juss.) extracts against foodborne pathogens and spoilage bacteria. Foodborne pathogens and disease, 4(4), 481-488.

Malik, M., Tahir, M. J., Jabbar, R., Ahmed, A., and Hussain, R. (2020). Self-medication during Covid-19 pandemic: challenges and opportunities. Drugs Ther Perspect. 3, 1-3.

Marquele, F. D., Stracieri, K. M., Fonseca, M. J. V., \& Freitas, L. A. P. (2006). Spray-dried propolis extract. I: physicochemical and antioxidant properties. Die Pharmazie-An International Journal of Pharmaceutical Sciences, 61(4), 325-330.

Masood, S., Rehman, W., Begum, S., Khan, Z., Gulnar, L. (2020). Drug-drug and drug-solvent interaction studies of Chloroquine phosphate, Acefylline piperazine and Gentamicin sulfate in polymeric systems. Arabian J. Chem., 13, 62216235 .

Noriega, P., Mafud, D. D. F., Souza, B. D., Soares-Scott, M., Rivelli, D. P., Barros, S. B. D. M., \& Bacchi, E. M. (2012). Applying design of experiments (DOE) to flavonoid extraction from Passiflora alata and P. edulis. Revista Brasileira de Farmacognosia, 22(5), 1119-1129.

Nugraha, R.V., Ridwansyah, H., Ghozali, M., Khairani, A. F., \& Atik, N. (2020). Traditional Herbal Medicine Candidates as Complementary Treatments for COVID-19: A Review of Their Mechanisms, Pros and Cons, Evidence-Based Comp. Altern. Med., 2020, 1-12.

Pang, S. F., Yusoff, M. M., \& Gimbun, J. (2014). Extraction and microencapsulation of polyphenols from Orthosiphon stamineus leaves. J. Mechanical Eng. Sci., 7, 1033-1041.

Park, Ji-Y., Kim, J. H., Kwon, J M., Kwon, H-J., Jeong, H. J., Kim, Y. M., Kim, D., Lee, W. S., Ryu, Y. B. (2013). Dieckol, a SARS-CoV 3CL(pro) inhibitor, isolated from the edible brown algae Ecklonia cava, Bioorg Med Chem., 21(13), 3730-3737.

Paris, R., Viejo, J. P. (1955). Identification des drogues simples et contrôle des médicaments végétaux par chromatographie sur papier. Presse Medicale, 63 (39), 833-834.

Patwardhan B, Warude D, Pushpangadan P, and Bhatt N. (2005). Ayurveda and traditional Chinese medicine: a comparative overview. Evid Based Comp. Altern. Med.,2(4), 465-473.

Qian, Z. Z., Dan, Y., Liu, Z., and Peng, Y. (2010). Pharmacopoeia of the People's Republic of China (2010 edition): a milestone in development of China's healthcare. Chin. Herb. Medicines, 2 (2), 157-160.

Rallabandi, H.R., Mekapogu, M., Natesan, K., Saindane, M., Dhupal, M., Swamy, M. K., \& Vasamsetti, B. M. K. (2020). Book: Plant-derived Bioactives: Computational Methods Used in Phytocompound-Based Drug Discovery, Springer Nature Singapore Pte Ltd., 549-560.

Rezende, Y. R. R. S., Nogueira, J. P., \& Narain, N. (2018). Microencapsulation of extracts of bioactive compounds obtained from acerola (Malpighia emarginata DC) pulp and residue by spray and freeze drying: Chemical, morphological and chemometric characterization. Food Chem., 254, 281-291. 
Rohr, G. E., Meier, B. and Sticher, O. (1999). Quantitative Reversed-Phase High-Performance Liquid Chromatography of Procyanidins in Crataegus Leaves and Flowers. J. Chromatogr. A, 835(1-2), 59-65.

Rong, H., Zhao, Y., Lazou, K., De Keukeleire, D., Milligan, S.R. and Sandra, P. (2000). Quantitation of 8Prenylnaringenin, a Novel Phytoestrogen in Hops (Humulus lupulus L.), Hop Products, and Beers, by Benchtop HPLCMS Using Electrospray Ionization. Chromatographia, 51(910), 545-552.

Sablania, V., Bosco, S. J. D., Rohilla, S., \& Shah, M. A. (2018). Microencapsulation of Murraya koenigii L. leaf extract using spray drying. J. Food Meas. Charac., 12(2), 892-901.

Saikia, S., Mahnot, N. K., \& Mahanta, C. L. (2015). Optimisation of phenolic extraction from Averrhoa carambola pomace by response surface methodology and its microencapsulation by spray and freeze drying. Food chemistry, 171, 144-152.

Santos, V. R., \& Pereira, E. M. R. (2018). Antifungal activity of Brazilian medicinal plants against Candida species. In Candida albicans. Intech Open.

Sarkar, S., Gupta, S., Variyar, P. S., Sharma, A., \& Singhal, R. S. (2013). Hydrophobic derivatives of guar gum hydrolyzate and gum Arabic as matrices for microencapsulation of mint oil. Carbohydrate polymers, 95(1), 177-182.

Senguttuvan, J., \& Subramaniam, P. (2016). HPTLC Fingerprints of Various Secondary Metabolites in the Traditional Medicinal Herb Hypochaeris radicata L. Journal of Botany, 2016, 1-11.

Shafique, S., Shafique, S., \& Sahar, S. (2020). Thymus serpyllum-a novel biocontrol agent against leaf spot pathogens of solanum melongena. Pak. J. Weed Sci. Res, 26(4), 469-479.

Shahidi Noghabi, M., \& Molaveisi, M. (2020). Microencapsulation optimization of cinnamon essential oil in the matrices of gum Arabic, maltodextrin, and inulin by spray-drying using mixture design. J. Food Proc. Eng., 43(2), e13341.

Sharma V. and Sarkar I.N. (2013). Bioinformatics opportunities for identification and study of medicinal plants. Briefings Bioinform., 14(2), 238-250.

Shofinita, D., \& Langrish, T. A. G. (2014). Spray drying of orange peel extracts: Yield, total phenolic content, and economic evaluation. J. Food Eng., 139, 31-42.

Singh V \& Garg A N. (1997). Availability of essential trace elements in ayurvedic indian medicinal herbs using instrumental neutron activation analysis. App. Rad. Isotopes. 48 (1), 97-101.

Smyslova, O.A. Bokov, D.O., Potanina, O.G., Litvinova, T.M., and Samylina. I.A. (2019). Development and validation of spectrophotometric procedure for quantitative determination of flavonoid content used to control the quality of mixture herbal product. J. Adv. Pharm. Technol. Res., 10(4), 155-162.

Souza, C. R. F., Georgetti, S. R., Salvador, M. J., Fonseca, M. J. V., \& Oliveira, W. P. (2009). Antioxidant activity and physical-chemical properties of spray and spouted bed dried extracts of Bauhinia forficata. Brazilian J. Pharmaceutical Sciences, 45(2), 209-218.

Souza, C. R. F., Schiavetto, I. A., Thomazini, F. C. F., \& Oliveira, W. P. (2008). Processing of Rosmarinus officinalis Linne extract on spray and spouted bed dryers. Brazilian J. Chem. Eng., 25(1), 59-69.

Steinmann, D., and Ganzera M.(2011). Recent advances on HPLC/MS in medicinal plant analysis. J. Pharm. Biomed. Anal., 55(4), 744-757.

Strohl W.R. (2000). The role of natural products in a modern drug discovery program. Drug Discov Today, 5, 39-41.

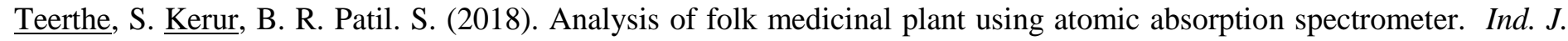
Pure App. Phy., 56(8):613-615.

Thompson, H. J. and Brown, S. A. (1984). Separation of Some Coumarins of Higher Plants by Liquid Chromatography, J. Chromatogr., 314, 323-336. 
Tülek, Z., Alaşalvar, H., Başyiğit, B., Berktas, S., Salum, P., Erbay, Z., \& Çam, M. (2021). Extraction optimization and microencapsulation of phenolic antioxidant compounds from lemon balm (Melissa officinalis L.): Instant soluble tea production. J. Food Process. Preservation, 45(1), e14995.

Vardin, H., \& Yasar, M. (2012). Optimisation of pomegranate (Punica Granatum L.) juice spray-drying as affected by temperature and maltodextrin content. Int. J. Food Sci. \& Technology, 47(1), 167-176.

Vidović, S. S., Vladić, J. Z., Vaštag, Ž. G., Zeković, Z. P., \& Popović, L. M. (2014). Maltodextrin as a carrier of health benefit compounds in Satureja montana dry powder extract obtained by spray drying technique. Powder Technology, 258, 209-215.

Vladić, J., Ambrus, R., Szabó-Révész, P., Vasić, A., Cvejin, A., Pavlić, B., \& Vidović, S. (2016). Recycling of filter tea industry by-products: Production of A. millefolium powder using spray drying technique. Ind. Crops Prod., 80, 197-206.

WHO Guidelines for Selecting Marker Substances of Herbal Origin for Quality Control of Herbal Medicines. Last accessed 2009 Apr 02]. Available from: http://apps.who.int/medicinedocs/documents/s23240en/s23240en.pdf .

Wittstock, U., Hadacek, F., Wurz, G., Teuscher, B. and Greger, H. (1995). Polyacetylenes from Water Hemlock (Cicuta virosa). Planta Medica, 61, 439-445.

Wulandari, L., Retnaningtyas, Y., Nuri, \& Lukman, H. (2016). Analysis of Flavonoid in Medicinal Plant Extract Using Infrared Spectroscopy and Chemometrics. J. Analytical Methods Chem., 2016, 1-6.

Yong E.L, Wong S.P, Shen P, Gong Y.H, Li J., Hong Y. (2007). Standardization and evaluation of botanical mixtures: Lessons from a traditional Chinese Herb, Epimedium, with oestrogenic properties. Novartis Found Symp. 282, $173-188$.

Zou, X.-X, Huang, L.-Q, Cui, G.-H, Yuan, Q.-J. Peng, Y. Liu, Y. Xiao, P.-G. (2009), Genetic relationships of Atractylodes plants. Acta Pharmaceutica sinica. 44 (6), 680-686. 